\title{
Colloid-bound and dissolved phosphorus species in topsoil water extracts along a grassland transect from Cambisol to Stagnosol
}

\author{
Xiaoqian Jiang ${ }^{1}$, Roland Bol ${ }^{1}$, Barbara J. Cade-Menun ${ }^{2}$, Volker Nischwitz ${ }^{3}$, Sabine Willbold ${ }^{3}$, Sara L. Bauke ${ }^{4}$, \\ Harry Vereecken ${ }^{1}$, Wulf Amelung ${ }^{1,4}$, and Erwin Klumpp ${ }^{1}$ \\ ${ }^{1}$ Institute of Bio- and Geosciences, Agrosphere Institute (IBG-3), Forschungszentrum Jülich GmbH, Jülich, Germany \\ ${ }^{2}$ Swift Current Research and Development Centre, Agriculture and Agri-Food Canada, Box 1030, \\ 1 Airport Rd., Swift Current, SK, S9H 3X2 Canada \\ ${ }^{3}$ Central Institute for Engineering, Electronics and Analytics, Analytics (ZEA-3), Forschungszentrum Jülich GmbH, \\ Jülich, Germany \\ ${ }^{4}$ Institute of Crop Science and Resource Conservation, Soil Science and Soil Ecology, Nussallee 13, University of Bonn, \\ 53115 Bonn, Germany
}

Correspondence to: Barbara J. Cade-Menun (barbara.cade-menun@agr.gc.ca) and Erwin Klumpp (e.klumpp@ fz-juelich.de)

Received: 13 October 2016 - Discussion started: 14 October 2016

Revised: 30 January 2017 - Accepted: 31 January 2017 - Published: 9 March 2017

\begin{abstract}
Phosphorus (P) species in colloidal and "dissolved" soil fractions may have different distributions. To understand which P species are potentially involved, we obtained water extracts from the surface soils of a gradient from Cambisol, Stagnic Cambisol to Stagnosol from temperate grassland in Germany. These were filtered to $<450$ $\mathrm{nm}$, and divided into three procedurally defined fractions: small-sized colloids $(20-450 \mathrm{~nm})$, nano-sized colloids (1$20 \mathrm{~nm})$, and "dissolved P" $(<1 \mathrm{~nm})$, using asymmetric flow field-flow fractionation (AF4), as well as filtration for solution ${ }^{31} \mathrm{P}$-nuclear magnetic resonance (NMR) spectroscopy. The total $\mathrm{P}$ of soil water extracts increased in the order Cambisol $<$ Stagnic Cambisol $<$ Stagnosol due to increasing contributions from the dissolved $\mathrm{P}$ fraction. Associations of $\mathrm{C}-\mathrm{Fe} / \mathrm{Al}-\mathrm{PO}_{4}^{3-}$ /pyrophosphate were absent in nanosized $(1-20 \mathrm{~nm})$ colloids from the Cambisol but not in the Stagnosol. The ${ }^{31} \mathrm{P}-\mathrm{NMR}$ results indicated that this was accompanied by elevated portions of organic $\mathrm{P}$ in the order Cambisol $>$ Stagnic Cambisol $>$ Stagnosol. Across all soil types, elevated proportions of inositol hexakisphosphate (IHP) species (e.g., myo-, scyllo- and D-chiro-IHP) were associated with soil mineral particles (i.e., bulk soil and small-sized soil colloids), whereas other orthophosphate monoesters and phosphonates were found in the "dissolved" $\mathrm{P}$ fraction. We conclude that $\mathrm{P}$ species composition varies among colloidal and "dissolved" soil fractions after charac-
\end{abstract}

terization using advanced techniques, i.e., AF4 and NMR. Furthermore, stagnic properties affect $P$ speciation and availability by potentially releasing dissolved inorganic and esterbound $\mathrm{P}$ forms as well as nano-sized organic matter-Fe/Al-P colloids.

Copyright statement. The works published in this journal are distributed under the Creative Commons Attribution 3.0 License. This license does not affect the Crown copyright work, which is re-usable under the Open Government Licence (OGL). The Creative Commons Attribution 3.0 License and the OGL are interoperable and do not conflict with, reduce or limit each other. The co-author Barbara J. Cade-Menun is an employee of the Canadian Government. She therefore claims Crown Copyright for her contributions.

(C) Crown copyright 2017

\section{Introduction}

Phosphorus $(\mathrm{P})$ is an essential nutrient for plant growth and limits terrestrial ecosystem productivity in many arable and grassland soils (Vance et al., 2003). The availability and transport of $\mathrm{P}$ depend on the speciation and concentration of $\mathrm{P}$ in the soil solution, which contains both "dissolved" 
and colloidal P forms (Shand et al., 2000; Hens and Merckx, 2002; Toor and Sims, 2015). Dissolved orthophosphate is generally the main $\mathrm{P}$ species in solution and can be directly taken up by plant roots (Condron et al., 2005; Pierzynski et al., 2005). However, colloidal $P$ in the size range of 1-1000 nm (Sinaj et al., 1998) may also contribute significantly to total P content in the soil solution (Haygarth et al., 1997; Shand et al., 2000; Hens and Merckx, 2001). Recent studies found that fine colloids $(<450 \mathrm{~nm}$ fraction) in soil water extracts consisted of nano-sized $(<20 \mathrm{~nm})$ and smallsized $(20<d<450 \mathrm{~nm})$ particles with different organic matter and elemental composition (Henderson et al., 2012; Jiang et al., 2015a). Very fine nano-sized $P$ colloids, around $5 \mathrm{~nm}$ are even prone to plant uptake (Carpita et al., 1979). In addition, the presence of fine colloids alters the free ionic $\mathrm{P}$ content in the soil solution through sorption processes (Montalvo et al., 2015). After diffusion-limited uptake depletes the free ionic $\mathrm{P}$ in the soil solution, these fine colloids disperse in the diffusion layer and therewith re-supply free ionic $\mathrm{P}$ species for roots (Montalvo et al., 2015). Because water-dispersible colloids (WDCs) can be easily released from soil in contact with water (Jiang et al., 2012; Rieckh et al., 2015), they have also been suggested as model compounds for mobile soil colloids (de Jonge et al., 2004; Séquaris et al., 2013). However, little is known about the chemical composition of $\mathrm{P}$ species in different-sized WDCs.

Recent studies have started to characterize natural fine colloidal $\mathrm{P}$ in freshwater samples and soil water extracts using asymmetric flow field-flow fractionation (AF4) coupled to various detectors (e.g., ultraviolet, UV, and inductively coupled plasma mass spectrometer, ICP-MS) for improved size fractionation of colloids and online analysis of their elemental composition (Henderson et al., 2012; Regelink et al., 2013; Gottselig et al., 2014; Jiang et al., 2015a). These analyses are increasingly combined with solution ${ }^{31} \mathrm{P}$-nuclear magnetic resonance (NMR) spectroscopy, which offers low detection limits and can quantify different inorganic and organic P compound groups (Cade-Menun, 2005; Cade-Menun and Liu, 2014) in isolated colloidal materials (e.g., Liu et al., 2014; Jiang et al., 2015a, b; Missong et al., 2016). However, we are not aware of studies that have applied these methods systematically to WDCs obtained from different major reference soils. Here, we focus on the comparison of Cambisols and Stagnosols. In contrast to Cambisols, Stagnosols are soils with perched water forming redoximorphic features. Due to temporary water saturation and resulting oxygen limitation, the reduction of iron $\left(\mathrm{Fe}^{\mathrm{III}}\right)$ is accompanied by the dissolution of its oxides and hydroxides (Rennert et al., 2014), and the $\mathrm{P}$ associated with these $\mathrm{Fe}$ minerals should correspondingly be redistributed in the soil solution.

The objective of this study was to elucidate how stagnant water conditions alter the potential release of different $P$ compounds in colloidal and "dissolved" fractions of the soil solution. For this purpose, water-extractable $\mathrm{P}$ was obtained from a transect of Cambisols to Stagnosols in a German tem- perate grassland, and characterized using both solution ${ }^{31} \mathrm{P}-$ NMR and AF4 coupled online with UV and organic carbon detector (OCD) or ICP-MS analyses.

\section{Materials and methods}

\subsection{Site description}

The grassland test site in Rollesbroich is located in the northern part of the Eifel in North Rhine-Westphalia, Germany $\left(50^{\circ} 62^{\prime} \mathrm{N}, 06^{\circ} 30^{\prime} \mathrm{E}\right)$. The grassland vegetation is dominated by perennial ryegrass (Lolium perenne L.) and smooth meadow grass (Poa pratensis L.). According to the soil map of the geological service of North Rhine-Westphalia (Fig. 1), the dominant soil types on the test site are Cambisols (extensive meadow with three to four cuts per year, no cattle grazing), Stagnic Cambisols (cattle pasture but with less frequent grazing than the Stagnosols), and Stagnosols (intensively used as pasture with frequent cattle grazing followed by harrowing with a tire-drag harrow and application of organic manure (cattle slurry): classification according to IUSS Working Group WRB (2015). The elevation along the transect generally decreases from south to north, with the highest elevation of $512.9 \mathrm{~m}$ a.s.l. at plot 1 and the lowest point of $505.1 \mathrm{~m}$ a.s.l. at plot 3 (Fig. 1, Table 1). The catchment mean annual precipitation was $103.3 \mathrm{~cm}$ for the period from 1981 to 2001, and the highest runoff occurred during winter due to high precipitation and low evapotranspiration rates, as well as overland flow due to saturation excess (Gebler et al., 2015). The topsoil samples $(2-15 \mathrm{~cm})$ of plot 1 (S1-1, S1-2, and S1-3, Cambisol), 2 (S2, Stagnic Cambisol), and 3 (S3-1, S3-2, and S3-3, Stagnosol) were taken as a representative transect across the site in early March 2015 (Fig. 1). It is worth noting that Stagnic water conditions do not mean that the soils are under reduced conditions for the whole year - only for some significant time of the year. We sampled a Stagnosol, but only the topsoil $(2-15 \mathrm{~cm})$, which was not under perching water, i.e., it was aerobic at time of sampling. However, at other times of the year, these soils experienced periods of reducing conditions that did not occur in the other samples along the transect. Surface turf $(0-2 \mathrm{~cm})$ was removed as it contained predominantly grass roots and little mineral soil. Removal of this very surface turf may also help minimizing effects from recent manure input on soil properties. Stones and large pieces of plant material were removed by hand. All samples were sieved immediately to $<5 \mathrm{~mm}$ and stored at $5{ }^{\circ} \mathrm{C}$.

\subsection{Water-dispersible fine colloids (WDFCs) separations and AF4-UV-ICP-MS/ AF4-UV-OCD analyses}

The WDCs of Rollesbroich grassland soil samples with three field replicates in S1 and S3 were fractionated using the soil particle-size fractionation method of Séquaris and 
Table 1. General soil characteristics and concentrations $\left(\mathrm{g} \mathrm{kg}^{-1}\right.$ soil) of total organic carbon (TOC), total Fe, Al, P, and $\mathrm{Si}$ in bulk $\mathrm{S} 1$ (Cambisol), S2 (Stagnic Cambisol), and S3 (Stagnosol). The lowercase letters indicate significant differences among soil sites (significant difference of soil site 1 and 3 was tested by $t$ test; $p<0.05)$.

\begin{tabular}{|c|c|c|c|c|c|c|c|c|}
\hline Soil & $\mathrm{pH}^{\mathrm{d}}$ & $\begin{array}{r}\text { Water } \\
\text { content }(\%)\end{array}$ & $\begin{array}{c}\text { Elevation } \\
\text { (ma.s.l.) }\end{array}$ & $\begin{array}{r}\text { TOC } \\
\left(\mathrm{g} \mathrm{kg}^{-1}\right)\end{array}$ & $\begin{array}{r}\mathrm{Fe}^{\mathrm{e}} \\
\left(\mathrm{g} \mathrm{kg}^{-1}\right)\end{array}$ & $\begin{array}{r}\mathrm{Al} \\
\left(\mathrm{g} \mathrm{kg}^{-1}\right)\end{array}$ & $\begin{array}{r}\mathrm{P} \\
\left(\mathrm{g} \mathrm{kg}^{-1}\right)\end{array}$ & $\begin{array}{r}\mathrm{Si} \\
\left(\mathrm{g} \mathrm{kg}^{-1}\right)\end{array}$ \\
\hline $\mathrm{S} 1^{\mathrm{a}}$ & $4.90 \pm 0.12 \mathrm{a}$ & $46.5 \pm 2.9$ & 512.9 & $35.6 \pm 2.3 \mathrm{a}^{*}$ & $23.0 \pm 1.1 \mathrm{a}^{*}$ & $52.6 \pm 2.9 \mathrm{a}$ & $1.2 \pm 0.1 \mathrm{a}$ & $320 \pm 7.6$ \\
\hline $\mathrm{S} 2^{\mathrm{b}}$ & 4.90 & 45.3 & 507.5 & 35.8 & $24.0 \pm 0.4$ & $54.0 \pm 2.0$ & $1.3 \pm 0.1$ & $320 \pm 7.0$ \\
\hline $\mathrm{S} 3^{\mathrm{c}}$ & $5.36 \pm 0.20 \mathrm{~b}$ & $59.0 \pm 7.6$ & 505.1 & $71.1 \pm 15.1 b^{*}$ & $12.8 \pm 0.4 b^{*}$ & $38.7 \pm 1.1 b$ & $1.8 \pm 0.4 \mathrm{~b}$ & $312 \pm 12.1$ \\
\hline
\end{tabular}

a The mean of samples S1-1, S1-2, and S1-3 \pm standard deviation. ${ }^{\mathrm{b}}$ The mean of three replicates of sample S2 \pm standard deviation. ${ }^{\mathrm{c}}$ The mean of samples S3-1, S3-2, and S3-3 \pm standard deviation. ${ }^{\mathrm{d}}$ The mass ratio of soil: water $=1: 2.5$. ${ }^{\mathrm{e}}$ Data were log transformed before $t$ test analyses because of unequal variances.

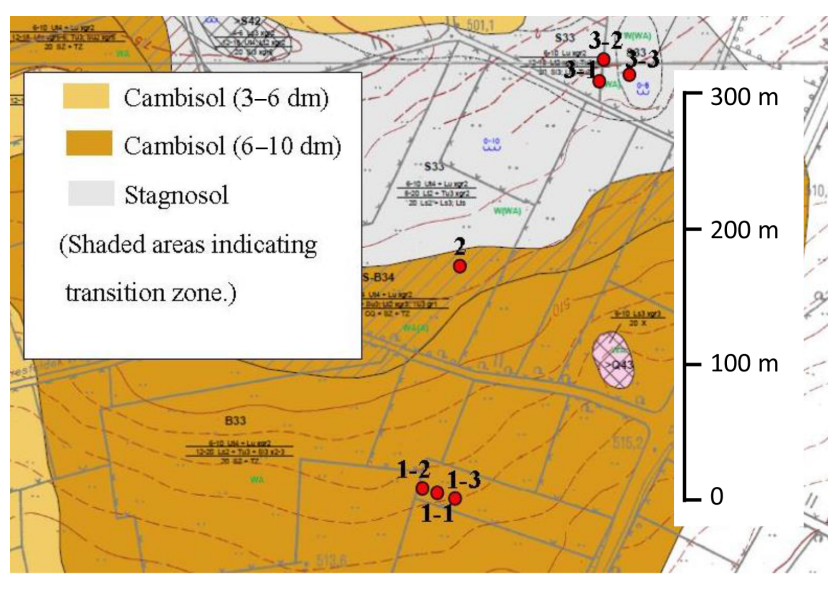

Figure 1. Excerpt from the soil map of the test site at Rollesbroich (modified from Geologischer Dienst Nordrhein-Westfalen, 2008). Numbered red dots indicate location of plots.

Lewandowski (2003), but with moist soils. In brief, moist soil samples ( $100 \mathrm{~g}$ of dry soil basis) were suspended in ultrapure water (Mill-Q; pH: 5.5) in a soil: solution mass ratio of $1: 2$, and shaken for $6 \mathrm{~h}$. Thereafter, $600 \mathrm{~mL}$ of ultrapure water were added and mixed. The WDC suspensions were collected using a pipette after a $12 \mathrm{~h}$ sedimentation period. These WDC suspensions were subsequently centrifuged for $15 \mathrm{~min}$ at $10000 \times g$ and filtered through $0.45 \mu \mathrm{m}$ membranes (cellulose mixing ester) to produce the suspension containing WDFCs sized below $0.45 \mu \mathrm{m}$. It is worth noting that Mill$\mathrm{Q}$ water was used here to extract soil colloids instead of rain water or pore water, since total amounts of WDFCs will likely be larger when using Mill-Q water, i.e., we consider these WDFCs as potentially water-dispersible colloids. In addition, the use of Mill-Q water facilitates subsequent sample processing with AF4 and NMR. It is inevitable that Mill-Q water would result in the release of $\mathrm{P}$ due to desorption and dissolution of poorly crystalline authigenic mineral phases. Additionally, living cells within the soil would also certainly undergo significant osmotic stress, likely resulting in osmotic rupture and releasing organic and inorganic $\mathrm{P}$ found in intracellular components. It is also worth noting that the exper- imental procedure with Mill-Q water under oxic conditions may have an impact on oxidation of aqueous iron $\left(\mathrm{Fe}^{2+}\right)$ and colloidal ferrous particles. However, at time of sampling, the very surface soils were not fully water saturated to what is allowed, even for Stagnosols at this time of the year. Thus, the analyzed species and size fractions are representative of differences in response to the extraction procedure based on different soil redox conditions that reflect a kind of legacy of former redox cycles, but at time of sampling and analyses the soils were aerobic.

An AF4 system (Postnova, Landsberg, Germany) with a $1 \mathrm{kDa}$ polyethersulfone (PES) membrane and $500 \mu \mathrm{m}$ spacer was used for size fractionation of the soil sample WDFCs. It is a separation technique that provides a continuous separation of colloids. The retention time of the colloids can be converted to hydrodynamic diameters of the colloids using AF4 theory or calibration with suitable standards (Dubascoux et al., 2010). The AF4 was coupled online to an ICPMS system (Agilent 7500, Agilent Technologies, Japan) for monitoring of the $\mathrm{Fe}$, aluminum $(\mathrm{Al})$, silicon $(\mathrm{Si})$, and $\mathrm{P}$ contents of the size-separated particles (Nischwitz and GoenagaInfante, 2012) and to OCD and UV detectors for measuring organic carbon (OC). These elements were analyzed as part of the main soil minerals (e.g., clay minerals and $\mathrm{Fe}$ oxides) that can be associated with P (Jiang et al., 2015a). The OCD is a promising technique for monitoring OC concentrations for liquid-flow-based separation systems with the advantages of high selectivity and low detection limits (Nischwitz et al., 2016). Briefly, the operation principle is that the acidification of the sample flow removes inorganic $\mathrm{C}$ and subsequently the $\mathrm{OC}$ is oxidized in a thin film reactor to carbon dioxide, which can be quantified by infrared detection (Nischwitz et al., 2016). A $25 \mu \mathrm{M} \mathrm{NaCl}$ solution at pH 5.5, which provided good separation conditions for the WDFCs, served as the carrier. The injected sample volume was $0.5 \mathrm{~mL}$ and the focusing time was $15 \mathrm{~min}$ with $2.5 \mathrm{~mL} \mathrm{~min}^{-1}$ cross-flow for the AF4-UV-OCD system while $2 \mathrm{~mL}$ injected volume and $25 \mathrm{~min}$ focusing time were used for the AF4-ICP-MS system. Thereafter, the cross-flow was maintained at $2.5 \mathrm{~mL} \mathrm{~min}^{-1}$ for the first $8 \mathrm{~min}$ of elution time, then set to decrease linearly to $0.1 \mathrm{~mL} \mathrm{~min}^{-1}$ within $30 \mathrm{~min}$, 

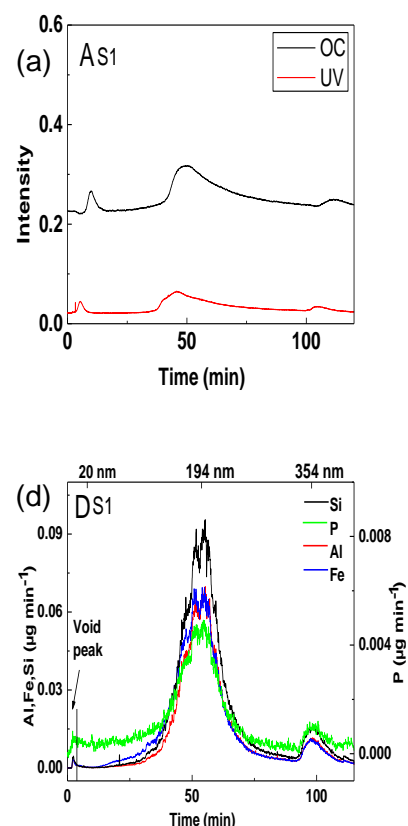
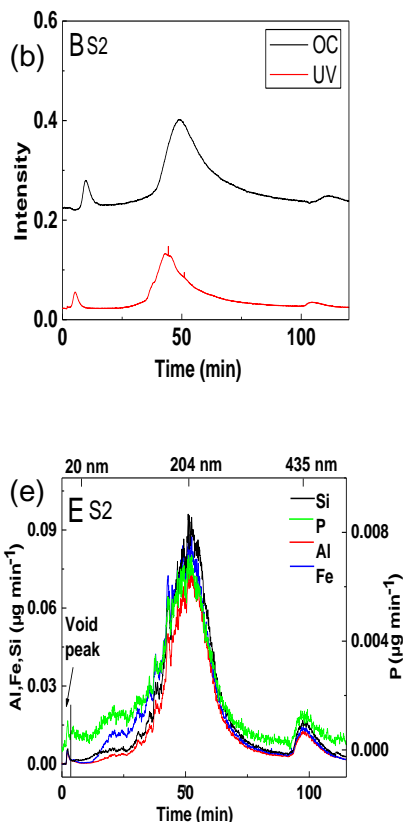
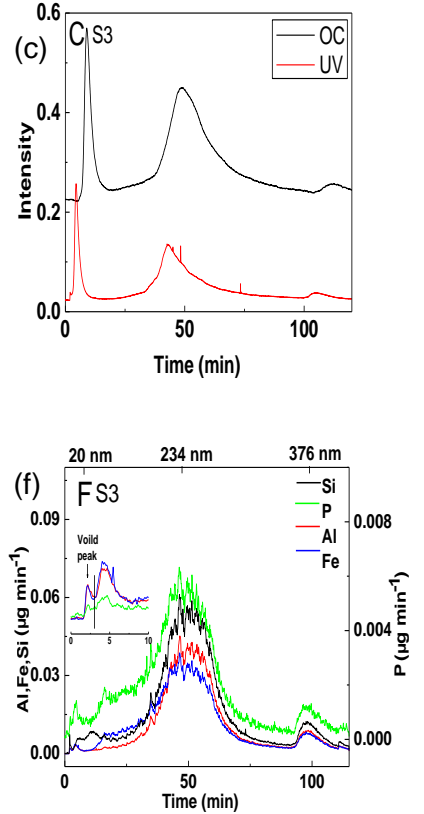

Figure 2. Asymmetric flow field-flow fractionation (AF4) fractograms of water-dispersible fine colloids (WDFCs) of S1, S2, and S3. The fractograms show the organic carbon (OC) and ultraviolet (UV) signal intensities (a, b, c) and the Fe, Al, P, and Si mass flow (d, e, f) monitored by inductively coupled plasma mass spectrometer (ICP-MS) of S1 (Cambisol), S2 (Stagnic Cambisol), and S3 (Stagnosol). The sizes of peaks were according to the AF4 result of sulfate latex standard particles and dynamic light scattering results. The OC and UV peaks occurred with elements (ICP-MS) peaks at the same time and the slight delay among these peaks is due to the different length of tubes to different detectors, which cause slightly different internal volume and retention time.

and maintained for $60 \mathrm{~min}$. It then declined within 2 min to $0 \mathrm{~mL} \mathrm{~min}^{-1}$, and remained at this rate for $20 \mathrm{~min}$ to elute the residual particles. The detection limit of the ICP-MS system was $0.1-1 \mu \mathrm{g} \mathrm{L}^{-1}$ for the elements analyzed in this study. The AF4 characteristics of WDFCs did not change significantly in the 6-month period of the investigation.

\subsection{Particle separations of WDFCs and solution ${ }^{31} \mathrm{P}-\mathrm{NMR}$ spectroscopy}

The soil samples were treated as described in Sect. 2.2 to obtain the suspension containing WDFCs $<450 \mathrm{~nm}$. We pooled the WDFC suspensions of the field replicates in order to receive sufficient samples for solution ${ }^{31} \mathrm{P}-\mathrm{NMR}$. The first peak fraction after AF4 separation has a particle size smaller than $\sim 20 \mathrm{~nm}$ (approximately $300 \mathrm{kDa}$; Jiang et al., 2015a; Fig. 2). Therefore, the suspension containing WDFCs $<450 \mathrm{~nm}$ of these three samples were separated into three size fractions: $300 \mathrm{kDa}-450 \mathrm{~nm}, 3-300 \mathrm{kDa}$, and $<3 \mathrm{kDa}$ (nominally $1 \mathrm{~nm}$; Erickson, 2009). The $300 \mathrm{kDa}-450 \mathrm{~nm}$ particle fractions were separated by passing $\sim 600 \mathrm{~mL}$ of the WDFC suspension through a $300 \mathrm{kDa}$ filter (Sartorius, Germany) by centrifugation. The $3-300 \mathrm{kDa}$ particle fractions were subsequently isolated by passing the $<300 \mathrm{kDa}$ supernatant through a $3 \mathrm{kDa}$ filter (Millipore Amicon Ultra) by centrifugation. Finally, the final supernatant containing the
$<3 \mathrm{kDa}$ particles as well as the electrolyte phase was frozen and subsequently lyophilized.

The bulk soil samples ( $1 \mathrm{~g})$ and the three fractions of soil water extracts were respectively mixed with $10 \mathrm{~mL}$ of a solution containing $0.25 \mathrm{M} \mathrm{NaOH}$ and $0.05 \mathrm{M} \mathrm{Na}_{2}$ EDTA (ethylenediaminetetraacetate) for $4 \mathrm{~h}$, as a variation of the method developed to extract $\mathrm{P}$ for ${ }^{31} \mathrm{P}-\mathrm{NMR}$ (Cade-Menun and Preston, 1996; Cade-Menun and Liu, 2014; Liu et al., 2014). Extracts were centrifuged at $10000 \times g$ for $30 \mathrm{~min}$ and the supernatant was frozen and lyophilized. Each $\mathrm{NaOH}-\mathrm{Na}_{2}$ EDTA-treated lyophilized extract, and the $<3 \mathrm{kDa}$ fraction without $\mathrm{NaOH}-\mathrm{Na}_{2}$ EDTA treatment, were dissolved in $0.05 \mathrm{~mL}$ of deuterium oxide $\left(\mathrm{D}_{2} \mathrm{O}\right)$ and $0.45 \mathrm{~mL}$ of a solution containing $1.0 \mathrm{M} \mathrm{NaOH}$ and $0.1 \mathrm{M} \mathrm{Na}_{2}$ EDTA (Turner et al., 2007). A $10 \mu \mathrm{L}$ aliquot of $\mathrm{NaOD}$ was added to the $<3 \mathrm{kDa}$ fraction without $\mathrm{NaOH}-\mathrm{Na}_{2}$ EDTA treatment to adjust the $\mathrm{pH}$. The prepared samples were centrifuged at $13200 \times g$ for $20 \mathrm{~min}$ (Centrifuge 5415R, Eppendorf).

Solution ${ }^{31} \mathrm{P}-\mathrm{NMR}$ spectra were obtained using a Bruker Avance $600 \mathrm{MHz}$ spectrometer equipped with a prodigy probe (a broadband CryoProbe, which uses nitrogen $(\mathrm{N})$ cooled RF coils and preamplifiers to deliver a sensitivity enhancement over room temperature probes of a factor of 2 to 3 for $\mathrm{X}$-nuclei from ${ }^{15} \mathrm{~N}$ to ${ }^{31} \mathrm{P}$ ), operating at $242.95 \mathrm{MHz}$ for ${ }^{31} \mathrm{P}$. Extracts were measured with a $\mathrm{D}_{2} \mathrm{O}$ field lock at room temperature. Chemical shifts were referenced to $85 \%$ or- 
thophosphoric acid ( $0 \mathrm{ppm})$. The NMR parameters generally used were $32 \mathrm{~K}$ data points, $3.6 \mathrm{~s}$ repetition delay, $0.7 \mathrm{~s}$ acquisition time, $30^{\circ}$ pulse width and 10000 scans. Compounds were identified by their chemical shifts after the orthophosphate peak in each spectrum was standardized to $6.0 \mathrm{ppm}$ during processing (Cade-Menun et al., 2010; Young et al., 2013). Peak areas were calculated by integration on spectra processed with 7 and $2 \mathrm{~Hz}$ line broadening, using NUTS software (2000 edition; Acorn NMR, Livermore, CA) and manual calculation. Peaks were identified as reported earlier (Cade-Menun, 2015), and by spiking a select sample with myo-inositol hexakisphosphate (myo-IHP; McDowell et al., 2007).

\subsection{Statistical analyses}

Elemental concentrations in bulk soils, soil water extracts, and AF4 fractograms of soil colloidal particles were tested for significant differences (set to $P<0.05$ ) using Sigmaplot version 12.5. A $t$ test was conducted to determine the significance of differences among soil sites, whereas one-way Repeated Measures (RM) ANOVA followed by post hoc separation of means using the Fisher LSC procedure to test for significant differences among soil fractions and AF4 fractograms for Cambisol and Stagnosol. Data were assessed with Shapiro-Wilks and Brown-Forsythe tests to meet the criteria of normal distribution and homogeneity of variances respectively; those which had unequal variance data were $\log _{10}$ transformed before statistical analyses.

\section{Results and discussion}

\subsection{Colloid and colloidal $P$ distribution in different size fractions based on AF4-fractograms}

The AF4-UV-OCD and AF4-ICP-MS results of the WDFCs showed different $\mathrm{OC}, \mathrm{Si}, \mathrm{P}, \mathrm{Fe}$, and $\mathrm{Al}$ concentrations in different-sized colloid fractions as a function of elution time (Fig. 2). Before the first peak, an initial small void peak occurred at $1 \mathrm{~min}$ (Fig. 2d, e, f). Thereafter, three different colloid-sized fractions occurred individually as three peaks in the WDFCs of all samples (Fig. 2). The first peak of the fractograms corresponded to a particle size below $20 \mathrm{~nm}$ according to the calibration result using latex standards (Jiang et al., 2015a). The third peak, which was eluted without cross-flow, contained only small amounts of residual particles or particles possibly previously attached on the membrane during focus time; it had similar OC and element distributions as the second peak in all samples (Fig. 2). Therefore, we considered these two fractions together as a whole, and the size ranges from 20 to $450 \mathrm{~nm}$ from here onward are described as the "second size fraction".

For the first fraction representing nano-sized colloids of the three field sites, the OCD and UV signals indicated increasing OC concentration in the order of S1 (Cambisol;
Fig. 2a), S2 (Stagnic Cambisol; Fig. 2b), and S3 (Stagnosol; Fig. 2c). Distinct peaks of $\mathrm{Fe}, \mathrm{Al}$, and $\mathrm{P}$ in the first size fraction $(<20 \mathrm{~nm})$ were only present in the Stagnosol (S3; Fig. 2f), suggesting that under stagnant water conditions, $\mathrm{Fe} / \mathrm{Al}$ may more readily be involved in nano-sized soil particles than under other soil conditions. In contrast, negligible amount of $\mathrm{P}, \mathrm{Al}$, and $\mathrm{Fe}$ were detected in the first fraction of S1 and S2 (Fig. 2d and e, Table S1). While it is sometimes difficult to determine whether this peak is real or just the tailing of the void signal (Fig. $2 \mathrm{~d}$ and e), solution ${ }^{31} \mathrm{P}$ NMR results confirmed the presence of $\mathrm{P}$ in this size fraction (see next section). The nano-sized colloids from the Cambisol contained $\mathrm{OC}$ and negligible $\mathrm{P}, \mathrm{Fe}$, and $\mathrm{Al}$; those from the Stagnosol contained significantly higher concentrations of $\mathrm{OC}, \mathrm{P}, \mathrm{Fe}$, and $\mathrm{Al}$ (Table S1). We therefore assumed that the nano-sized colloidal $\mathrm{P}$ forms in the Stagnosol mainly consisted of $\mathrm{OC}-\mathrm{Fe}(\mathrm{Al})-\mathrm{P}$ associations. Nanoparticulate humic (organic matter)-Fe (Al) (ions/(hydr)oxide)-phosphate associations have recently been identified both in water and soil samples (Gerke, 2010; Regelink et al., 2013; Jiang et al., 2015a). Our results suggest that the formation of these nanosized specific $\mathrm{P}$ associations is favored by the stagnant water conditions with high OC and water contents in Stagnosol but not in the other soil types along the grassland transect.

The second size fraction (Fig. 2a, b, c, i.e., the small-sized colloids) contained significantly more OC than the smaller nano-sized colloids for all studied soils (Table S1). Notably, the OC contents of the second fraction increased in the order Cambisol $<$ Stagnic Cambisol $<$ Stagnosol; the UV signal therein supporting the results obtained with the OC detector. The larger-sized colloids were significantly richer in $\mathrm{Al}$, $\mathrm{Fe}, \mathrm{Si}$, and $\mathrm{P}$ than the smaller-sized ones (Table S1), though again with differences among subsites; the Stagnic Cambisol showed the largest $\mathrm{Fe}, \mathrm{Al}$, and $\mathrm{Si}$ contents in the second fraction, as if there were a gradual change from low WDFC release in the Cambisol to the formation of larger WDFC in the Stagnic Cambisol and finally to the formation of smaller WDFC in the Stagnosol. Though this trend warrants verification by more sites, it appeared at least as if the increasing oxygen limitation from Cambisols via Stagnic Cambisols to Stagnosols promoted an increasing formation of small Crich $\mathrm{P}$-containing nanoparticles with additional contributions from Fe- and Al-containing mineral phases. Stagnosols like S3 are characterized by a dynamic reduction regime with dissolution of reactive Fe oxides (Rennert et al., 2014), which led to a decrease in the content of Fe oxides in the second colloidal fraction (Table S1 in the Supplement). Correspondingly, the dissolution of Fe oxides in the second fraction under stagnant water may also liberate $\mathrm{OC}$ from the organo-Fe mineral associations, thus releasing some OC to the nanosized first fraction (Jiang et al., 2015a). This could be an additional reason for the higher concentration of OC in the first peak of S3 (Table S1), apart from a generally slower degradation of organic matter under limited oxygen supply (Rennert et al., 2014). Hence, the AF4 results indicated that the 


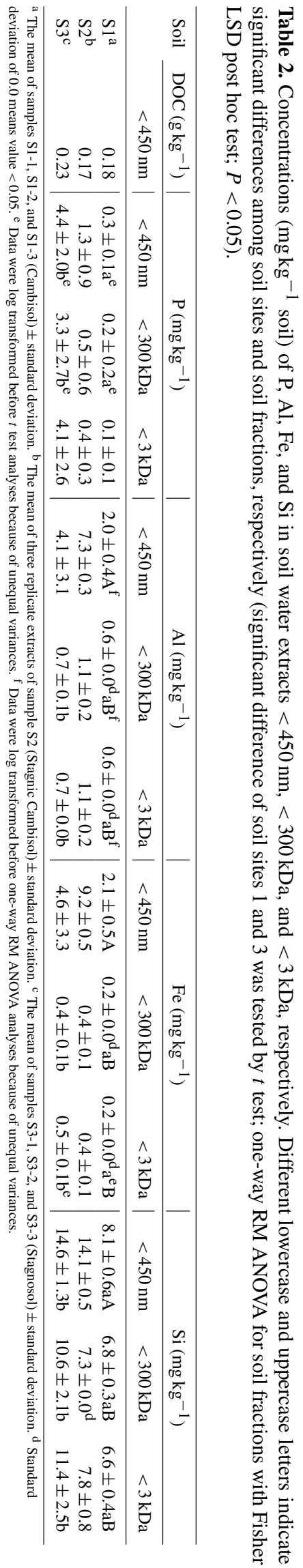

composition and distribution of particulate $\mathrm{P}$ varied among the different-sized colloidal particles, and that its properties were impacted by the soil type and related properties. However, AF4-ICP-MS results do not provide information about the elemental concentrations of the "dissolved" $P$ fraction of these grassland soils. We cannot rule out any effects from sample storage or from the use of Mill-Q water, as discussed in the Methods section, However, although all samples were treated the same way, differences among the samples were consistent with soil characteristics at each site. This suggests that the influences of treatment and storage were minimal, but further investigation is warranted in future studies.

\subsection{Soil total, colloidal, and dissolved $P$ contents based on fractionation by filtration}

Soil water extracts $<450 \mathrm{~nm},<300 \mathrm{kDa}$, and $<3 \mathrm{kDa}$ were obtained by filtration to determine total elemental contents by ICP-MS analysis. Data did not have to be pooled for these analyses; therefore, we could test statistical differences. We considered the soil water extract $<3 \mathrm{kDa}$ in this paper to be the "dissolved" fraction. Significant differences $(P<0.05)$ were ascertained for elevated concentrations of total organic carbon (TOC), total P, as well for lower concentrations of total $\mathrm{Al}$ and $\mathrm{Fe}$ in the Stagnosol relative to the Cambisol (Table 1). Furthermore, the Stagnosol had significantly higher concentrations of $\mathrm{Si}$ and $\mathrm{P}$ in the individual size fractions of soil water extracts (except marginally significantly higher $\mathrm{P}$ in $<3 \mathrm{kDa}, p=0.06$ ), as well as higher $\mathrm{Fe}$ and $\mathrm{Al}$ concentrations in $<300 \mathrm{kDa}$ and $<3$ fractions than the corresponding fractions of the Cambisol (Table 2). The Stagnic Cambisol generally resembled the Cambisol rather than the Stagnosol in bulk soil analysis, but this was not the case for the soil water extracts. This implied that the stagnic properties have a greater impact on the colloidal particles and "dissolved" fraction compared to bulk soil.

The oxygen limitation and reduction regime of the Stagnosol probably also favored the accumulation of OC and dissolution of $\mathrm{Fe}$ oxides both in bulk soil and colloids (Rennert et al., 2014). Dissolution of Fe oxides in turn results in a disaggregation of colloidal particles (Jiang et al., 2015a). As the released oxides are main carriers for $\mathrm{P}$, these processes may explain why the distribution of colloidal and dissolved $\mathrm{P}$ also changed across the different grassland soils. As Table 2 shows, large proportions of $\mathrm{P}$ in the $<450 \mathrm{~nm}$ fraction of the Stagnosol were dissolved P (i.e., recovered here in the $<3 \mathrm{kDa}$ fraction), whereas colloidal $\mathrm{P}$ dominated in the Cambisol and Stagnic Cambisol.

\subsection{Inorganic and organic $P$ species in the different-sized soil colloidal and the "dissolved" fractions}

Solution ${ }^{31} \mathrm{P}-\mathrm{NMR}$ was used to elucidate the speciation of $\mathrm{P}$ in bulk soil and soil water extracts separated by ultrafil- 
Table 3. The proportion (\%) of phosphorus species ${ }^{\text {a }}$ determined by solution ${ }^{31} \mathrm{P}-\mathrm{NMR}$ for the different soil fractions of S1 (Cambisol), S2 (Stagnic Cambisol), and S3 (Stagnosol).

\begin{tabular}{|c|c|c|c|c|c|c|c|c|c|c|}
\hline \multirow[t]{2}{*}{ Soil fractions } & $P_{i}$ & $\mathrm{P}_{\mathrm{o}}$ & Ortho-P & Pyro-P & Poly & P-mono & P-mono ${ }^{b}$ & P-diest & P-diest ${ }^{b}$ & Phon-P \\
\hline & \multicolumn{10}{|c|}{$\%$} \\
\hline S1 bulk & 43.4 & 56.6 & 41.2 & 1.5 & 0.7 & 52.9 & 44.5 & 2.2 & 10.6 & 1.5 \\
\hline S2 bulk & 47.8 & 52.2 & 46.4 & 0.9 & 0.5 & 48.6 & 43.7 & 1.4 & 6.3 & 2.2 \\
\hline S3 bulk & 63.7 & 36.3 & 63.0 & 0.2 & 0.5 & 31.2 & 27.0 & 1.5 & 5.7 & 3.6 \\
\hline $\mathrm{S} 1300 \mathrm{kDa}-450 \mathrm{~nm}$ & 22.8 & 77.2 & 22.8 & $-^{\mathrm{c}}$ & - & 56.7 & 49.5 & 11.1 & 18.3 & 9.4 \\
\hline $\mathrm{S} 2300 \mathrm{kDa}-450 \mathrm{~nm}$ & 56.8 & 43.2 & 53.1 & 1.0 & 2.7 & 29.9 & 26.9 & 5.2 & 8.2 & 8.1 \\
\hline $\mathrm{S} 3300 \mathrm{kDa}-450 \mathrm{~nm}$ & 70.2 & 29.8 & 59.7 & 9.2 & 1.3 & 24.2 & 19.9 & 2.8 & 7.1 & 2.8 \\
\hline S1 3-300 kDa & 100 & - & 100 & - & - & - & - & - & - & - \\
\hline S2 3-300 kDa & 100 & - & 100 & - & - & - & - & - & - & - \\
\hline S3 3-300 kDa & 100 & - & 61.5 & 38.5 & - & - & - & - & - & - \\
\hline $\mathrm{S} 1<3 \mathrm{kDa}$ & 13.5 & 86.5 & - & - & 13.5 & 26.9 & 26.9 & 1.9 & 1.9 & 57.7 \\
\hline $\mathrm{S} 2<3 \mathrm{kDa}$ & 21.3 & 78.7 & 9.5 & 5.1 & 6.7 & 29.3 & 13.8 & 24.2 & 34.6 & 25.2 \\
\hline $\mathrm{S} 3<3 \mathrm{kDa}$ & 22.2 & 77.8 & 8.8 & 6.0 & 7.4 & 29.4 & 27.4 & 8.2 & 10.2 & 40.2 \\
\hline
\end{tabular}

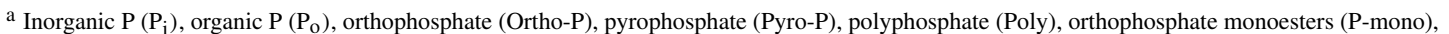
orthophosphate diesters (P-diest), phosphonates (Phon-P). ${ }^{\mathrm{b}}$ Recalculation by including diester degradation products ( $\alpha$ glycerophosphate, $\beta$ glycerophosphate, and mononucleotides) with P-diest rather than P-mono (Liu et al., 2014; Young et al., 2013). ${ }^{\mathrm{c}}$ Below detection limit, i.e., $<0.05 \%$.

tration into the size fractions $300 \mathrm{kDa}-450 \mathrm{~nm}, 3-300 \mathrm{kDa}$, and $<3 \mathrm{kDa}$ for each of the three soils (Figs. 3 and $\mathrm{S} 1$ in the Supplement, Table 3). The identified $\mathrm{P}$ included inorganic $\mathrm{P}$ forms (orthophosphate, pyrophosphate, and polyphosphate), and organic $\mathrm{P}$ in phosphonate, orthophosphate monoester, and diester compound classes. Phosphonates included 2-aminoethyl phosphonic acid (AEP) and several unidentified peaks (Table S3). Orthophosphate monoesters included four stereoisomers of inositol hexakisphosphate (myo-, scyllo-, neo-, and D-chiro-IHP), diester degradation products ( $\alpha$ glycerophosphate, $\beta$ glycerophosphate and mononucleotides), choline phosphate, and unidentified peaks at 3.4, 4.2, 4.7, 5.0, 5.3, and $5.9 \mathrm{ppm}$. Orthophosphate diesters were divided into deoxyribonucleic acid (DNA) and two categories of unknown diesters (OthDi1 and OthDi2, respectively). Orthophosphate, pyrophosphate, orthophosphate monoesters, and diesters have also been detected in other studies of grassland, arable, and forest Cambisols and Stagnosols (e.g., Murphy et al., 2009; Turrion et al., 2010; Jarosch et al., 2015).

For the bulk soil samples and colloidal fractions of $300 \mathrm{kDa}-450 \mathrm{~nm}$ of our soil samples, orthophosphate and orthophosphate monoesters (mainly myo-IHP) were the main $\mathrm{P}$ compounds in all samples (Figs. 3 and S1, Tables 3 and S2). These main $P$ compounds in these two soil fractions showed similar trends among the soil samples: the proportions of organic P (e.g., orthophosphate monoesters and diesters) decreased in the order of Cambisol $>$ Stagnic Cambisol $>$ Stagnosol (Table 3). The similarity in this trend for the different organic $\mathrm{P}$ forms can likely be attributed to similarities in the mineral components of bulk soil and colloidal fractions: i.e., similar element concentrations and thus likely also similar clay mineralogy, Fe oxide signature and OC con-

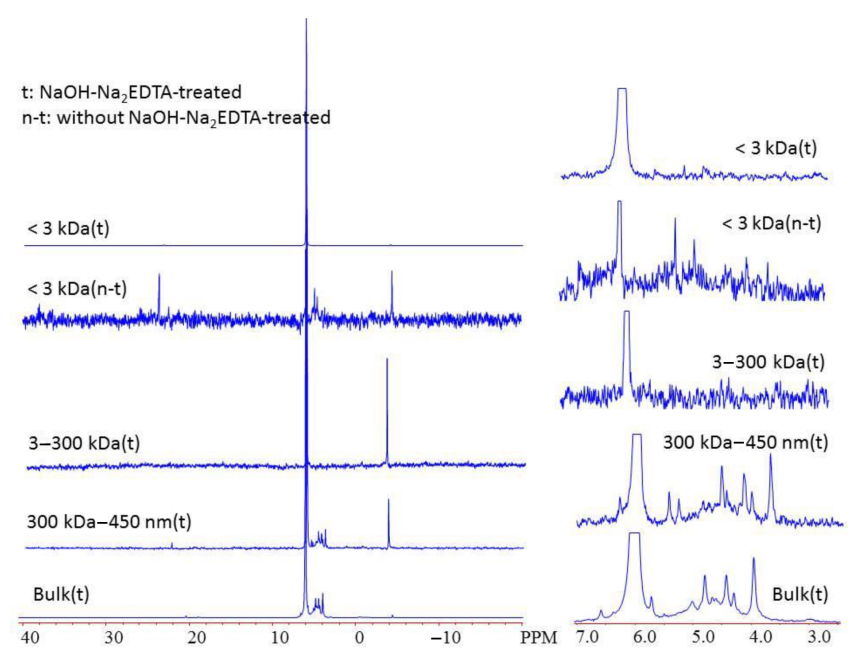

Figure 3. Solution phosphorus-31 nuclear magnetic resonance spectra of $\mathrm{NaOH}-\mathrm{Na}_{2}$ EDTA extracts of bulk soil, $300 \mathrm{kDa}-450 \mathrm{~nm}$, $3-300 \mathrm{kDa}$, and $<3 \mathrm{kDa}$ fractions in soil water extracts $<450 \mathrm{~nm}$ of S3 (Stagnosol).

tent of bulk soil, and respective colloid fraction according to the AF4-OCD and AF4-ICP-MS results (Fig. 2 and Table S1). Orthophosphate, orthophosphate monoesters, and diesters are predominantly stabilized by association with these mineral components (Solomon and Lehmann, 2000; Turner et al., 2005; Jiang et al., 2015a). We assume that most of the relatively higher proportion of orthophosphate and lower percentage of organic $\mathrm{P}$ in the Stagnosol may be attributed to the dissolution of Fe oxides, which likely released organic P. Additionally, the higher concentrations of $\mathrm{OC}$ in both bulk soil (Table 1) and large colloids of the Stagnosol probably 
favored the formation of OC-Fe/Al-PO ${ }_{4}^{3-}$ complexes (see above). However, we cannot rule out the effects of differences in grazing and manure application on the $\mathrm{P}$ forms in these soils. Cattle grazing and the application of cattle slurry would be expected to add $P$ that is predominantly orthophosphate, with lower concentrations of organic $\mathrm{P}$ forms including myo-IHP (Cade-Menun, 2011, and references therein). Thus, this may have contributed to the increased orthophosphate and decreased organic $\mathrm{P}$ we observed on these sites.

Our study is the first to distinguish the chemical P composition in colloidal fractions of $3-300 \mathrm{kDa}$ and $300 \mathrm{kDa}-$ $450 \mathrm{~nm}$. We found different $\mathrm{P}$ speciation and distribution between these two fractions. This is probably related to differences in their element composition, which are dominated by $\mathrm{OC}-\mathrm{P} / \mathrm{OC}-\mathrm{Fe}(\mathrm{Al})-\mathrm{P}$ associations in the $3-300 \mathrm{kDa}$ soil fraction and by clay-Fe oxides-OC-P associations in the $300 \mathrm{kDa}-450 \mathrm{~nm}$ size fraction (Fig. 2). Intriguingly, we did not find any organic $\mathrm{P}$ but only inorganic $\mathrm{P}$ in the 3$300 \mathrm{kDa}$ of all three soils (orthophosphate in Cambisol and Stagnic Cambisol, orthophosphate and pyrophosphate in the Stagnosol; Table 3). Furthermore, the Stagnosol nanoparticle fraction 3-300 kDa had a higher proportion of pyrophosphate than the $300 \mathrm{kDa}-450 \mathrm{~nm}$ size fraction.

When comparing the solution ${ }^{31} \mathrm{P}-\mathrm{NMR}$ results of the $<3 \mathrm{kDa}$ soil fractions with and without $\mathrm{NaOH}-\mathrm{Na}_{2}$ EDTA treatments (Figs. 3 and S1), we observed that most of the phosphonates, orthophosphate monoesters, and diesters were lost after $\mathrm{NaOH}-\mathrm{Na}_{2}$ EDTA treatment (Figs. 3 and S1). There were two possible explanations: (1) "dissolved" organic P in the $\mathrm{NaOH}-\mathrm{Na}_{2}$ EDTA solution is sensitive and easily hydrolyzed to orthophosphate (Cade-Menun and Liu, 2014); or (2) in absence of $\mathrm{NaOH}-\mathrm{Na}_{2}$ EDTA, most orthophosphate was removed by adsorption on sedimentary material in the re-dissolved solution after centrifugation when preparing the samples for NMR analysis (Cade-Menun and Liu, 2014), resulting in elevated portions of organic $\mathrm{P}$ in the NMR sample. The second possibility may also explain the observation that there was no orthophosphate in the "dissolved" fraction of the Cambisol without $\mathrm{NaOH}-\mathrm{Na}_{2}$ EDTA treatment (Fig. S1). Almost all the orthophosphate may have been removed with the sedimentary phase due to the extremely low concentration of dissolved $\mathrm{P}$ in this soil. Therefore, we will focus on the discussion of results obtained from the $<3 \mathrm{kDa}$ soil fractions without $\mathrm{NaOH}-\mathrm{Na}_{2}$ EDTA treatment, as they provide better information on the origin of $\mathrm{P}_{\mathrm{o}}$ species than the other samples that received this treatment.

The composition of $\mathrm{P}$ species in the $<3 \mathrm{kDa}$ soil fractions (i.e., "truly" dissolved P) differed among the three soils (Table 3). The majority of observed $\mathrm{P}$ in the $<3 \mathrm{kDa}$ soil fraction of the Cambisol was organic P, comprised mainly of phosphonates and orthophosphate monoesters. The $<3 \mathrm{kDa}$ soil fraction of the Stagnic Cambisol contained various P species from all compound classes, including orthophosphate, orthophosphate monoesters, orthophosphate diesters, pyrophosphate, polyphosphates, and phosphonates.
The $<3 \mathrm{kDa}$ soil fraction of the Stagnosol contained similar $P$ species as the Stagnic Cambisol, with relatively higher proportions of orthophosphate monoesters and phosphonates, but a lower proportion of orthophosphate diesters (Table 3). It is worth noting that there were more species of phosphonates in the $<3 \mathrm{kDa}$ fraction than other fractions of each soil (Figs. 3 and S1). The larger signal at $\sim 21-23.5 \mathrm{ppm}$ was assigned to AEP (Doolette et al., 2009; Cade-Menun, 2015), which occurred in both the soil particles and the $<3 \mathrm{kDa}$ fraction. However, the small signals at $\sim 36-39$ and $45-$ $46 \mathrm{ppm}$ existed only in the $<3 \mathrm{kDa}$ fraction of soil samples (Figs. 3 and S1). The resonance at 36-39 ppm might be assigned to dimethyl methyl phosphonic acid, based on CadeMenun (2015). However, spiking experiments were not conducted to identify peaks in this region, so their specific identity and origins remain unknown.

The solution ${ }^{31} \mathrm{P}-\mathrm{NMR}$ results showed that $\mathrm{P}$ species composition in the two colloidal fractions and the electrolyte phase differed among all three soil samples, with more phosphonates potentially existing in the electrolyte phase. However, in the study of Missong et al. (2016), more phosphonates and orthophosphate diesters were found in colloidal fractions rather than the electrolyte phase of two forest Cambisols. Missong et al. (2016) used centrifugation while we used filtration to separate these particle sizes and phases. Additionally, Missong et al. (2016) worked with forest soils while we worked with grassland soils. McLaren et al. (2015) recently confirmed that the speciation of organic $\mathrm{P}$ is markedly different between high $(>10 \mathrm{kDa})$ and low $(<10 \mathrm{kDa})$ molecular weight fractions of soil extracts. In any case, both colloidal aggregation and changes in soil order paralleled $\mathrm{P}$ forms. However, other soil properties (like $\mathrm{pH}$ ) and former redox states, as well as variations in anthropogenic, site-adapted management may be additional covariates affecting $\mathrm{P}$ colloids and composition.

\subsection{Distribution of orthophosphate monoesters and pyrophosphate}

With variations in overall $\mathrm{P}$ species composition, the proportions of certain species of orthophosphate monoesters were also distributed differently among the investigated fractions of the three soils. For example, the proportion of various IHP stereoisomers (i.e., myo-, scyllo-, D-chiro-IHP) decreased with decreasing colloid size (Table S2). This suggests that the majority of IHP was associated with soil mineral particles but did not exist in the dissolved form in our soil samples. The myo-IHP stereoisomer is the principal input of inositol phosphate to soil in the form of plant material (Turner et al., 2002) and the other stereoisomers may come from plants or may be synthesized by soil organisms (Caldwell and Black, 1958; Giles et al., 2015). Inositol phosphate is stabilized mainly through strong adsorption on the surface of amorphous metal oxides and clay minerals (Celi and Barberis, 2007). Shang et al. (1992) found myo-IHP sorbed onto $\mathrm{Al}$ and $\mathrm{Fe}$ ox- 
ides to a greater extent than glucose 6-phosphate. Several orthophosphate monoesters such as unknown peaks at 3.4, 4.7, and $5.9 \mathrm{ppm}$ were only detected in the electrolyte phase of soil samples (Table S2). The differences in orthophosphate monoester species distribution between soil particles and the electrolyte phase show that soil minerals such as clay minerals and $\mathrm{Fe}(\mathrm{Al})$ oxides are only associated with certain species of orthophosphate monoesters such as IHP, while other species of orthophosphate monoesters exist only in the electrolyte phase. Further research is warranted to fully understand the factors controlling $\mathrm{P}_{\mathrm{O}}$ in these different size fractions.

It is worth noting that although the proportion of pyrophosphate in bulk soil was very low, there was more pyrophosphate in the colloidal and electrolyte phases of the Stagnic Cambisol and the Stagnosol than in the Cambisol, and mostly in the electrolyte and nano-sized colloidal fraction (Table 3). Our former study (Jiang et al., 2015b) indicated that $\mathrm{Fe} / \mathrm{Al}$ oxides were not the main bonding site for pyrophosphate adsorption in different-sized fractions of an arable soil. Considering that a high proportion of pyrophosphate $(38.5 \%)$ existed in the $3-300 \mathrm{kDa}$ fraction of the Stagnosol, which contained $\mathrm{P}$ mainly in $\mathrm{OC}-\mathrm{Fe}(\mathrm{Al})^{2 / 3+}$ $\mathrm{P}$ associations (see above), it seems reasonable to assume that pyrophosphate existed as a colloidal $\mathrm{OC}-\mathrm{Fe}(\mathrm{Al})^{2 / 3+}$ pyrophosphate complex. In this regard, the accumulation of pyrophosphate may have been favored by the larger OC contents in this soil (Fig. 2c).
This study shows for the first time that $\mathrm{P}$ species composition varies among the electrolyte phase and colloids of different size, with the specific distribution being related to the stagnic water regime of the soil. It could potentially promote $\mathrm{P}$ availability by a mechanism that results in a loss of colloids, thus providing less surface area for the immediate bonding of inorganic $\mathrm{P}$ to minerals, while at the same time potentially releasing organic $\mathrm{P}$ from mineral bonding so that it is more prone to decomposition. Relating the static differences in $\mathrm{P}$ species composition among the different soils and fractions to true dynamics of $\mathrm{P}$ transformations, e.g., by performing controlled mesocosm experiments, now warrants further attention.

Data availability. The data set for this project is available at http: //juser.fz-juelich.de/record/827862/files/?ln=de. 


\section{Appendix A: Abbreviations}

\begin{tabular}{|c|c|}
\hline AEP & 2-Aminoethyl phosphonic acid \\
\hline AF4 & asymmetric flow field-flow fractionation \\
\hline $\mathrm{Al}$ & aluminum \\
\hline $\mathrm{Ca}$ & calcium \\
\hline DNA & deoxyribonucleic acid \\
\hline EDTA & Ethylenediaminetetraacetic \\
\hline $\mathrm{Fe}$ & iron \\
\hline FFF & field-flow fractionation \\
\hline ICP-MS & inductively coupled plasma mass spectrometer \\
\hline myo-IHP & myo-inositol hexakisphosphate \\
\hline $\mathrm{N}$ & nitrogen \\
\hline NMR & nuclear magnetic resonance \\
\hline $\mathrm{OC}$ & organic carbon \\
\hline OCD & organic carbon detector \\
\hline $\mathrm{OM}$ & organic matter \\
\hline PES & polyethersulfone \\
\hline$P_{i}$ & inorganic $\mathrm{P}$ species \\
\hline $\mathrm{P}_{\mathrm{o}}$ & organic $\mathrm{P}$ species \\
\hline $\mathrm{Si}$ & silicon \\
\hline UV & ultraviolet \\
\hline WDCs & water-dispersible colloids \\
\hline WDFCs & water-dispersible fine colloids \\
\hline
\end{tabular}




\section{Information about the Supplement}

The elemental concentrations in AF4 fractograms, phosphorus spectra and species determined by solution ${ }^{31} \mathrm{P}-\mathrm{NMR}$ as well as solution ${ }^{31} \mathrm{P}-\mathrm{NMR}$ chemical shifts of the $\mathrm{P}$ compounds are shown in the Supplement.

\section{The Supplement related to this article is available online} at doi:10.5194/bg-14-1153-2017-supplement.

Author contributions. X. Jiang contributed to all aspects of the project. E. Klumpp and R. Bol contributed to project design and initiation, field sampling and writing the paper. B. J. Cade-Menun assisted with the interpretation of NMR data and writing the paper. V. Nischwitz assisted with FFF measurement. S. Willbold conducted the NMR analyses. S. L. Bauke assisted with soil sampling and statistical analyses. H. Vereecken assisted with the discussion of results. W. Amelung assisted with the discussion of results and writing the paper.

Competing interests. The authors declare that they have no conflict of interest.

Acknowledgements. X. Jiang thanks the China Scholarship Council (CSC) for financial support and acknowledges C. Walraf and H. Philipp for technical assistance. The authors gratefully acknowledge the support by TERENO (Terrestrial Environmental Observatories) funded by the Helmholtz Association of German Research Centers.

Edited by: Y. Kuzyakov

Reviewed by: two anonymous referees

\section{References}

Cade-Menun, B. J.: Characterizing phosphorus in environmental and agricultural samples by ${ }^{31} \mathrm{P}$ nuclear magnetic resonance spectroscopy, Talanta, 66, 359-371, 2005.

Cade-Menun, B. J.: Characterizing phosphorus in animal waste with solution ${ }^{31} \mathrm{P}$ NMR spectroscopy, in: Environmental Chemistry of Animal Manure, edited by: He, Z., 275-299, Nova Science Publishers, Inc. New York, 2011.

Cade-Menun, B. J.: Improved peak identification in ${ }^{31}$ P-NMR spectra of environmental samples with a standardized method and peak library, Geoderma, 257-258, 102-114, 2015.

Cade-Menun, B. J. and Liu, C. W.: Solution ${ }^{31}$ P-NMR spectroscopy of soils from 2005-2013, A review of sample preparation and experimental parameters, Soil Sci. Soc. Am. J., 78, 19-37, 2014.

Cade-Menun, B. J. and Preston, C. M.: A comparison of soil extraction procedures for ${ }^{31} \mathrm{P}$ NMR spectroscopy, Soil Sci., 161, 770-785, 1996

Cade-Menun, B. J., Carter, M. R., James, D. C., and Liu, C. W.: Phosphorus forms and chemistry in the soil profile under longterm conservation tillage: A phosphorus-31 nuclear magnetic resonance study, J. Environ. Qual., 39, 1647-1656, 2010.
Caldwell, A. G. and Black, C. A.: Inositol hexaphosphate. II. Synthesis by soil microorganisms, Soil Sci. Soc. Am. P., 22, 293296, 1958.

Carpita, N., Sabularse, D., Montezinos, and Delmer, D.: Determination of the pore size of cell walls of living plant cells, Science, 205, 1144-1147, 1979.

Celi, L. and Barberis, E.: Abiotic reactions of inositol phosphates in soil, in: Inositol Phosphates, Linking Agriculture and the Environment, edited by: Turner, B. L., Richardson, A. E., and Mullaney, E. J., 207-220, CAB International, Wallingford, UK, 2007.

Condron, L. M., Turner, B. L., and Cade-Menun, B. J.: Chemistry and dynamics of soil organic phosphorus, in: Phosphorus: Agriculture and the Environment, edited by: Sims, J. T. and Sharpley, A. N., 87-121, ASA, CSA, SSSA, Madison, WI, 2005.

de Jonge, L. W., Moldrup, P., Rubæk, G. H., Schelde, K., and Djurhuus, J.: Particle leaching and particle-facilitated transport of phosphorus at field scale, Vadose Zone J., 3, 462-470, 2004.

Doolette, A. L., Smernik, R. J., and Dougherty, W. J.: Spiking improved solution phosphorus-31 nuclear magnetic resonance identification of soil phosphorus compounds, Soil Sci. Soc. Am. J., 73, 919-927, 2009.

Dubascoux, S., Le Hecho, I., Hassellöv, M., v. d. Kammer, F., Gautier, M. P., and Lespes, G.: Field-flow fractionation and inductively coupled plasma mass spectrometer coupling: history, development and applications, J. Anal. Atom. Spectrom., 25, 613$623,2010$.

Erickson, H. P.: Size and shape of protein molecules at the nanometer level determined by sedimentation, gel filtration, and electron microscopy, Biol. Proced. Online, 11, 32-5, 2009.

Gebler, S., Hendricks Franssen, H.-J., Pütz, T., Post, H., Schmidt, M., and Vereecken, H.: Actual evapotranspiration and precipitation measured by lysimeters: a comparison with eddy covariance and tipping bucket, Hydrol. Earth Syst. Sci., 19, 2145-2161, doi:10.5194/hess-19-2145-2015, 2015.

Gerke, J.: Humic (organic matter)-Al(Fe)-phosphate complexes: an underestimated phosphate form in soils and source of plantavailable phosphate, Soil Sci., 175, 417-425, 2010.

Giles, C. D., Lee, L. G., Cade-Menun, B. J., Hill, J. E., Isles, P. D. F., Schroth, A. W., and Druschel, G. K.: Characterization of organic phosphorus form and bioavailability in lake sediments using ${ }^{31} \mathrm{P}$ NMR and enzymatic hydrolysis, J. Environ. Qual., 44, 882-894, 2015.

Gottselig, N., Bol, R., Nischwitz, V., Vereecken, H., Amelung, W., and Klumpp, E.: Distribution of phosphorus-containing fine colloids and nanoparticles in stream water of a forest catchment, Vadose Zone J., 13, 1-11, 2014.

Haygarth, P. M., Warwick, M. S., and House, W. A.: Size distribution of colloidal molybdate reactive phosphorus in river waters and soil solution, Water Res., 31, 439-448, 1997.

Henderson, R., Kabengi, N., Mantripragada, N., Cabrera, M., Hassan, S., and Thompson, A.: Anoxia-induced release of colloidand nanoparticle-bound phosphorus in grassland soils, Environ. Sci. Technol., 46, 11727-11734, 2012.

Hens, M. and Merckx, R.: Functional characterization of colloidal phosphorus species in the soil solution of sandy soils, Environ. Sci. Technol., 35, 493-500, 2001. 
Hens, M. and Merckx, R.: The role of colloidal particles in the speciation and analysis of "dissolved" phosphorus, Water Res., 36, 1483-1492, 2002.

IUSS Working Group WRB: World Reference Base for Soil Resources 2014, update 2015, International soil classification system for naming soils, Wold Soil Resources Report 106, Food and Agriculture Organization of the United Nations, 2015.

Jarosch, K. A., Doolette, A. L., Smernik, R. J., Tamburini, F., Frossard, E., and Bünemann, E. K.: Characterisation of soil organic phosphorus in $\mathrm{NaOH}-\mathrm{EDTA}$ extracts: A comparison of ${ }^{31} \mathrm{P}$ NMR spectroscopy and enzyme addition assays, Soil Biol. Biochem., 91, 298-309, 2015.

Jiang, C., Séquaris, J.-M., Vereecken, H., and Klumpp, E.: Effects of inorganic and organic anions on the stability of illite and quartz soil colloids in Na-, $\mathrm{Ca}$ - and mixed $\mathrm{Na}-\mathrm{Ca}$ systems, Colloid. Surface. A, 415, 134-141, 2012.

Jiang, X., Bol, R., Nischwitz, V., Siebers, N., Willbold, S., Vereecken, H., Amelung, W., and Klumpp, E.: Phosphorus containing water dispersible nanoparticles in arable soil, J. Environ. Qual., 44, 1772-1781, 2015a.

Jiang, X., Bol, R., Willbold, S., Vereecken, H., and Klumpp, E.: Speciation and distribution of $\mathrm{P}$ associated with $\mathrm{Fe}$ and $\mathrm{Al}$ oxides in aggregate-sized fraction of an arable soil, Biogeosciences, 12, 6443-6452, doi:10.5194/bg-12-6443-2015, 2015 b.

Liu, J., Yang, J., Liang, X., Zhao, Y., Cade-Menun, B. J., and Hu, Y.: Molecular speciation of phosphorus present in readily dispersible colloids from agricultural soils, Soil Sci. Soc. Am. J., 78, 47-53, 2014.

McDowell, R. W., Cade-Menun, B., and Stewart, I.: Organic P speciation and pedogenesis: analysis by ${ }^{31} \mathrm{P}$ nuclear magnetic resonance spectroscopy, Eur. J. Soil Sci., 58, 1348-1357, 2007.

McLaren, T. I., Smernik, R. J., McLaughlin, M. J., McBeath, T. M., Kirby, J. K., Simpson, R. J., Guppy, C. N., Doolette A. L., and Richardson, A. E.: Complex forms of soil organic phosphorus A major component of soil phosphorus, Environ. Sci. Technol., 49, 13238-13245, 2015.

Missong, A., Bol, R., Willbold, S., Siemens, J., and Klumpp, E.: Phosphorus forms in forest soil colloids as revealed by liquidstate ${ }^{31}$ P-NMR. J. Plant Nutr. Soil Sc., 179, 159-167, 2016.

Montalvo, D., Degryse, F., and McLaughlin, M. J.: Natural colloidal $\mathrm{P}$ and its contribution to plant $\mathrm{P}$ uptake, Environ. Sci. Technol., 49, 3427-3434, 2015.

Murphy, P. N. C., Bell, A., and Turner, B. L.: Phosphorus speciation in temperate basaltic grassland soils by solution ${ }^{31} \mathrm{P}$ NMR spectroscopy, Eur. J. Soil Sci., 60, 638-651, 2009.

Nischwitz, V. and Goenaga-Infante, H.: Improved sample preparation and quality control for the characterisation of titanium dioxide nanoparticles in sunscreens using flow field flow fractionation on-line with inductively coupled plasma mass spectrometry, J. Anal. Atom. Spectrom., 27, 1084-1092, 2012.

Nischwitz, V., Gottselig, N., Missong, A., Meyn, T., and Klumpp, E.: Field flow fractionation online with ICP-MS as novel approach for the quantification of fine particulate carbon in stream water samples and soil extracts, J. Anal. Atom. Spectrom., 31, 1858-1868, 2016.

Pierzynski, G. M., McDowell, R. W., and Sims, J. T.: Chemistry, cycling and potential movement of inorganic phosphorus in soils, in: Phosphorus: agriculture and the environment, edited by: Sims,
J. T. and Sharpley, A. N., 53-86, ASA, CSA, SSSA, Madison, WI, 2005.

Regelink, I. C., Koopmans, G. F., van der Salm, C., Weng, L., and van Riemsdijk, W. H.: Characterization of colloidal phosphorus species in drainage waters from a clay soil using asymmetric flow field-flow fractionation, J. Environ. Qual., 42, 464-473, 2013.

Rennert, T., Händel, M., Höschen, C., Lugmeier, J., Steffens, M., and Totsche, K. U.: A NanoSIMS study on the distribution of soil organic matter, iron and manganese in a nodule from a Stagnosol, Eur. J. Soil Sci., 65, 684-692, 2014.

Rieckh, H., Gerke, H. H., Glæsner, N., and Kjaergaard, C.: Tracer, dissolved organic carbon, and colloid leaching from erosionaffected arable hillslope soils, Vadose Zone J., 14, 1539-1663, 2015.

Séquaris, J. M. and Lewandowski, H.: Physicochemical characterization of potential colloids from agricultural topsoils, Colloid. Surface. A, 217, 93-99, 2003.

Séquaris, J. M., Klumpp, E., and Vereecken, H.: Colloidal properties and potential release of water-dispersible colloids in an agricultural soil depth profile, Geoderma, 193-194, 94-101, 2013.

Shand, C. A., Smith, S., Edwards, A. C., and Fraser, A. R.: Distribution of phosphorus in particulate, colloidal and molecular-sized fractions of soil solution, Water Res., 34, 1278-1284, 2000.

Shang, C., Stewart, J. W. B., and Huang, P. M.: pH effect on kinetics of adsorption of organic and inorganic phosphates by shortrange ordered aluminum and iron precipitates, Geoderma, 53, 1$14,1992$.

Sinaj, S., Machler, F., Frossard, E., Faisse, C., Oberson, A., and Morel, C.: Interference of colloidal particles in the determination of orthophosphate concentrations in soil water extracts, Commun. Soil Sci. Plan., 29, 1091-1105, 1998.

Solomon, D. and Lehmann, J.: Loss of phosphorus from soil in semi-arid northern Tanzania as a result of cropping: evidence from sequential extraction and ${ }^{31} \mathrm{P}-\mathrm{NMR}$ spectroscopy, Eur. J. Soil Sci., 51, 699-708, 2000.

Toor, G. S. and Sims, J. T.: Managing phosphorus leaching in midAtlantic soils: importance of legacy sources, Vadose Zone J., 14, 1-12, 2015.

Turner, B., Condron, L., Richardson, S., Peltzer, D., and Allison, V.: Soil organic phosphorus transformations during pedogenesis, Ecosystems, 10, 1166-1181, 2007.

Turner, B. L., Papházy, M. J., Haygarth, P. M., and McKelvie, I. D.: Inositol phosphates in the environment, Philos. T. R. Soc. B, 357, 449-469, 2002.

Turner, B. L., Cade-Menun, B. J., Condron, L. M., and Newman, S.: Extraction of soil organic phosphorus, Talanta, 66, 294-306, 2005.

Turrion, M. B., Lafuente, F., Aroca, M. J., López, O., Mulas, R., and Ruipérez, C.: Characterization of soil phosphorus in a fire-affected forest Cambisol by chemical extractions and ${ }^{31} \mathrm{P}$ NMR spectroscopy analysis, Sci. Total Environ., 408, 33423348, 2010.

Vance, C. P., Uhde-Stone, C., and Allan, D. L.: Phosphorus acquisition and use: critical adaptations by plants for securing a nonrenewable resource, New Phytol., 157, 423-447, 2003.

Young, E. O., Ross, D. S., Cade-Menun, B. J., and Liu, C. W.: Phosphorus speciation in riparian soils: A phosphorus-31 nuclear magnetic resonance spectroscopy and enzyme hydrolysis study, Soil Sci. Soc. Am. J., 77, 1636-1647, 2013. 